\title{
Pés vivos in "El queso del quechua" by Glauco Mattoso
}

ALEJANDRO CASTRO

New York University

\begin{abstract}
This paper approaches "El queso del quechua," the Spanish-language translation of Brazilian writer Glauco Mattoso's short story "O quitute do quíchua," on the basis of certain central concepts: fetishism, anthropophagy, blindness, coprophagy, and sadomasochist entelechy. It intends to analyze the book itself, released by an Argentine cartonera publishing house, as an object, as well as the story contained within it. Cecilia Palmeiro translated the work, having already published research on the relationship between Mattoso's work and the consumption of waste. This paper explores the relation between the academy and the cultural field, as well as the presence of a living, acting, mutable, and performative element in Mattoso's literature.
\end{abstract}

Keywords: Poetry, Brazil, foot fetishism, psychoanalysis, anthropophagy

"The songs of my tongue have eyes and feet, eyes and feet, muscles, soul, feelings, the grandeur of heroes and small, modest customs, so simple, minimal, young and extremely simple, they howl with anguish, enormous, enormous, enormously enormous, they smile, they cry, they smile, they spit abuse at the sky or spew snakes, they work, they work just like people or birds" (Rokha 148).

The "songs of the tongue" and the feet will be key points of entry for examining a recently translated short story by Glauco Mattoso - the pseudonym of Pedro José Ferreira da Silva, a sociologist and librarian from São Paulo, born in 1951entitled "El queso del quechua" 'The Quechua's cheese' (2010) and an 
exceptionally complex device. It is, first of all, a short story that opens with a sonnet, also by the author, and it turns out to be the etiology of the sonnet and the story of another short story, one that a certain Nelo tells the narrator. Inevitably and maliciously confused with the author (of both the poem and the short story), the narrator barely introduces the "case" before inserting himself into the dialogue. "El queso del quechua" is also the translation, by Argentine researcher Cecilia Palmeiro, of "O quichute do quíchua" for a bilingual edition published by Eloísa Cartonera. Outside of this edition, the Portuguese original remained unprinted, though it was reproduced online, until it was included in the anthology Tripé do tripúdio e outros contos hediondos (2011).

Palmeiro obtained her doctorate at Princeton in 2009 with a dissertation that traces an explicit trajectory: subtitled "De la cartonera a Perlongher" 'From the cartonera to Perlongher' and later published as a book, it covers Brazil's desbunde generation and dedicates its second chapter to the personality of Mattoso. In her study, Palmeiro not only surveys but also takes part in a long tradition of cultural trafficking between Argentina and Brazil. In the same vein, Néstor Perlongher wrote the essay "O desejo do pé" in 1985, as the epilogue to Manual do podólatra amador: aventura \& leituras de um tarado por pés (2006), an autobiography of Mattoso, which also functions as an instruction manual and a form of advertisement for "podolatry" and BDSM practices. ${ }^{1}$

What can one say about the sonnet that opens Mattoso's short story? It is necessary first of all to observe its title: “926." By the end of the 1990s, Mattoso, already completely blind, embarked on the project 1100 sonetos em cinco anos, an uncommon operation in the domain of literature, in blatant competition with dead writers such as Giuseppe Belli, Manuel Maria Barbosa du Bocage, and Lope de Vega. He has become certainly, after establishing his record, the most prolific author of sonnets in the Portuguese language, or maybe any language. The poem " 926 " is, then, a number in a series, a sort of record, and, at the same time, a variation on the same, almost exclusive, meaningless theme that appears in nearly all of the sonnets: man's feet. The number 926, in conceptual terms, represents a significant part of the author's poetic project. It is similarly representative in formal terms, in that Mattoso's work almost always takes—allowing for some

\footnotetext{
1 "Podolatry," podolatria, is a term used by Mattoso, which combines the Latin podo- and -latria to refer to the adoration and worship of feet.
} 
metric variations - the form of a sonnet. The inevitable question is, Why still write sonnets today? Mattoso himself offers an answer:

Não considero que o soneto tenha sido formalmente superado. Faço minhas as palavras de Fausto Cunha a propósito do temporão, porém perene Livro de Sonetos (1949) de Jorge de Lima: "A própria questão do soneto como soneto tornar-se-ia, aqui, bizantina. Sempre vi (e mais de uma vez o escrevi) no soneto a maior conquista formal da poesia em todos os tempos, razão pela qual tenho olhado com ceticismo os que lhe agoiram a decadência." Dou-me ao luxo de pilheriar que o soneto vem a ser a maior invenção do Homem, depois da roda, do alfabeto latino, do algarismo arábico e da própria notação musical. (Geléia de rococó 123 )

The notion of genius - some sort of a creative will endowed with originality, an effective demiurge capable, like God, of materializing things ex nihilo-emerged during the European Renaissance and was later recovered, institutionalized, and as a result deformed by Romanticism. The tradition of ingenuity, however, is more ancient and runs parallel to the idea of genius. It is more tightly linked to the concept of composition, Baroque aesthetics, and the sonnet. For the authors of sonnets, the themes are given and encoded. Their task is then to focus on them in an ingenious way. The theme is an excuse for demonstrating a certain mastery of language, simply introducing a twist, the poet's contribution to a subject treated many times over. For instance, in the poetry of Gregório de Mattos (one of the influences for the pen name "Mattoso"), it is common to find returns "ao mesmo assumpto," rewritten verses that openly come from a dialogue with the tradition of Baroque poetry. Sor Juana Inés de la Cruz, one of Mattos's contemporaries, also titled many of her sonnets "Prosigue el mismo asunto" 'She continues with the same matter' (Barnstone 95).

Much the same thing occurs with some subgenres of painting. Still lives, for instance, are a kind of radical neutralization of the theme, as they set the scene for the elaboration and success of technique (or ingenuity). With regard to music, it is impossible not to mention jazz, which works based on the variations (infinite, as in the previous cases) on a basic theme (or melody), over which all the 
musicians construct their composition - that is, make their contribution. Sonnet 926 works as a still life, as a variation, and as a return to the same matter. It is situated, therefore, from a literary point of view, within a clearly Baroque tradition; from a pictorial point of view, it is a still life; from a musical point of view, it has the sound of jazz. Mattoso's choice of the foot as theme connects his work to the tale of Cinderella in A pata da gazela (1870), a Brazilian Romantic novel by José de Alencar, which Mattoso reinterprets in A planta da donzela (2005), and to the many verses that celebrate, in all languages and with more or less literary value, the foot.

In his preface to Mattoso's 2015 collection of sonnets, Jorge Sallum explains the writer's choice of this form by drawing on a notion that is also at the center of discussions of Mattoso's work developed by Palmeiro and by Steven Butterman: sacanagem. The term has been taken from the poet's reflections on his own work: "Se folclorista adora festas, antropólogo adora índio, psicólogo só pensa em significados, e militar tem fixação na disciplina, qual será o 'vício,' digamos, 'intelectual' do Glauquinho? Fácil: minha 'tara' é a própria, ou seja, a sacanagem" (118).

Why, other than for the sake of ironic distantiation, would anybody write sonnets at the end of the twentieth century? On the other hand, amidst the hordes of transgressors and lovers of formal experimentation, what could be more defiant than writing sonnets, with their fixed and eminently traditional form? Brazilian modernists and, in general, Latin American avant-garde movementseven the marginal poets of the Mimeograph Generation-destroyed the traditional formats of the poem in favor of free verse, and in so doing were probably unaware of the fact that that they were confining all hint of rhyme to popular culture (in songs and frivolous poems). As Sallum puts it: "Frequentar uma forma morta seria, por definição, um caso de necrofilia. Porém Glauco Mattoso é um famoso e assumido podólatra, um adorador de pés. E de pés vivos. Talvez não seja, então, coincidência que ele reafirme, por ação e criação, a vivacidade do soneto, uma forma montada em pés (pois metrificada)" (9).

It is worth pointing out that podolatry and necrophilia are not mutually exclusive. Paraphilia is essentially polymorphic, and it follows from this that the choice of form can itself be read as a sort of fetishism. One might justifiably argue that Mattoso, for example, has responded with necrophilia (through the "dead" form of the sonnet) to the Concretist avant-garde and its fascination with 
formal novelty and freedom. Mattoso responds to anthropophagy with coprophagy because, if what is at stake if the act of devouring, what does one do with the (mounting) detritus of culture, with the remains of these self-consciously cannibalistic practices of digestion ${ }^{2}$ What avant-garde poets choose to discard, he will consume. He responds with fetishism to marginal poetry, which is perhaps too full of itself and politically engaged, identified with marginality and the heroic. ${ }^{3}$ Whether Mattoso is, after all, a "great teaser," a necrophiliac, or a fetishist completely depends on a reading operation. But there is still something else visible behind (or through) his sacana, something that allows him to be grouped with (and decoupled from) the Marginals, the Concretists, and the Anthropophagists. In "O poeta passado a sujo," his introduction to Poesia digesta by Mattoso (2004), Pedro Ulysses Campos alludes to the words of Casaco (Antônio Carlos de Brito, the preeminent writer of the poesia marginal movement in Brazil): "Glauco Mattoso configura um caso à parte em nossa poesia: ele pega um pouco de tudo, come de tudo, bebe de tudo, prova de tudo. E desconfia de tudo. [...] Usa de tudo e não se prende a nada. [...] O poeta mete a língua na vida alheia, na língua alheia, na obra alheia, na dor alheia e na própria dor" (14).

Putting the tongue into the alheio is tasting what belongs to others but also what is strange, what is radically distant. Mattoso's ingenuity lies in that operation, which exceeds the distinction (and the tension) between form and content, between originality and skill: he is omnivorous. Mattoso chooses the sonnet "for the sake of teasing" because he is a necrophiliac and a fetishist, but also because he is blind: the metric structure favors memory. A man who has lost his vision seems to rediscover the music of words. Music, that is, mathematics.

\footnotetext{
${ }^{2}$ The famous Coprophagic Manifesto, published in the Jornal Dobrabil (2001), starts with an extraordinary paraphrase of the first verse of Federico García Lorca's "Romance sonámbulo" 'Sleepwalking ballad' (by one "García Loca") that reads: "Mierda que te quiero mierda" 'Shit how I love you shit' (11). The essential thesis of coprophagy materialized in the American academy thanks to Steven Butterman and has continued with the work of Cecilia Palmeiro. In essence, Glauco Mattoso - his brand name as an author, all his work, his persona, his political and aesthetic positions, his severe blindness, his fetishism of men's feet-represents the dark side of the anthropophagical project and its failure, "the complex and cynical process whereby Mattoso satirically transforms Oswaldian 'anthropofagia,' one of the most fundamental aesthetic principles of early Brazilian modernism, into 'coprofagia,' the inevitable postmodern extension - and indeed the final product — of the metaphor of literary cannibalism" (Butterman 113).

${ }^{3}$ See the analysis (and criticism) developed by Mattoso, the most marginal of the Marginals, on the coherence (and the disarticulation) of that generation in $O$ que é poesia marginal? (2006).
} 
This is so true - that is, Mattoso's work is so much a repertoire - that in 2001 Rotten Records Brazil, an independent record label, launched a record titled, Melopeia: sonetos musicados, with twenty-three sonnets by Mattoso sung by several folk, rock, and punk groups. Ana Paula Aparecida Caixeta has pointed out the clear similarity between the cover of Melopeia and that of Tropicália ou panis et circencis, a collaborative record released in 1968. All of these varying levels of complexity are certainly an extraordinary yet almost absurd maneuver of amplification. The foot is not the theme to which the poet returns; rather, it is the audible somatography through which all the themes, all the dilemmas of the Baroque, poesia marginal, Tropicália, and many other traditions, are displayed (Nancy, Corpus; Listening). Here is how sonnet 49 puts it:

A crítica que tenho recebido é quanto ao tema, não quanto ao formato:

"O Glauco trata só de pé e sapato, ainda que use o molde mais subido."

Respondo antes de tudo por Cupido: comigo ele jamais teve contato. Além do mais, não vou deixar barato que assunto algum me seja proibido.

Sou cego mas eclético, e versejo acerca de problemas tão diversos que nem forró, barroco e sertanejo.

De grandes e pequenos universos é feito o pé que cheiro, beijo e vejo: A Ele presto conta dos meus versos. (Geléia de rococó 56)

Just as Romantic poets believed to have found the universe in the bottom of their individual souls, and Baroque poets located it in the anxiety of incorporation, for Mattoso, an idolater, the foot is everything - he even capitalizes the pronoun ("Ele") he uses to refer to it. His work is fetishistic on several levels: first, in its selection of form and theme; and second, in even more general terms, because it 
turns "one part" into "the whole" (fetishism is a form of synecdoche). Furthermore, it is difficult to speak of fetishism without addressing the two great fields of intellectual debate in the twentieth-century West, Marxism and psychoanalysis, in both of which fetishism plays a crucial role.

In these fields, fetishism is tightly bound to blindness. Both Marx and Freud understand it as a problem of vision: every fetishist is blind. For Marx, what the fetishist cannot see is the work that turns a thing into a commodity. For Freud, it is castration. However, while Marx considers a thing to be a fetish when we take it to be only what we see (becoming blind to what is not visible: its manufacture), for Freud, a thing is a fetish when it is also what it is not, what it cannot be. Both are cases of substitution and elevation; however, Marx thinks there is a blind subject in relation to the labor that produces things, Freud proposes that there is a subject whose blindness is a scopic advantage, a type of work on things that can be transformed into their absence, their lack.

Mattoso's sonnet 926, which opens "O quichute do quíchua," reads as follows:

Em cada artelho um calo seu formato altera. Unha encravada causa inchaço no mínimo e no médio. Manca o passo de dor, que aumenta o aperto no sapato.

Dizer que aquele pé seria chato é pouco: se na sola os olhos passo, tão reta me parece, que não faço nenhuma distinção dum pé de pato.

O grande artelho dos demais se aparta e tem no comprimento só a metade do dedo "indicador." Cantiga é farta nos vãos, onde a frieira está à vontade. Tal pé serve-me à língua e, se a descarta, podólatra não acha que lhe agrade. (17) 
A specialist would say the poem is written in the form of a Petrarchan sonnet, as there are fourteen verses of ten syllables each, with an ABBA rhyme scheme in the quatrains and a CDC rhyme scheme in the tercets. "It's the description of a foot," a reader not initiated in gore podolatry would say with some repugnance. But it is not a foot but that foot, or an absolutely particularized foot, and what particularizes it is certainly not its beauty. It is a sick, deformed, putrefied, and fetid foot. Antonio Vicente Seraphim Pietroforte admits, also with repugnance, that it is "difícil apreciar uma literatura marcada pela tortura, e não pela carícia, e por pés na maioria sujos e grosseiros, ao invés de pés suaves e delicados” (182), and he resolves the question by concentrating on the elevated aesthetics of Mattoso's poems: “Coloca seu entusiasmo erótico em função da depuração minuciosa dos versos" (183). In other words, it is disgusting but well written.

It is difficult to deny, in fact, that Mattoso is knowledgeable and virtuosic. His literary, historiographical, and theoretical production encompasses more than fifty books: poetry, short stories, novels, translations, songbooks, essays, and even an impeccable Tratado de versificação that has been praised as the most complete treatise on poetic form in the Portuguese language. One must remember, however, that all this synergy, all this production and knowledge, are at the service of that which is explicitly foul. Sonnet 926 is a clear example of this: scene after scene, it is the story - halfway between clinical and cynical — of the mark of identity of a foot that is damaged, aches, and stinks. This tradition of singing a sensual hymn to damage, to what aches and stinks, is as ancient as Western poetry. Consider Catullus, Francisco de Quevedo, Antônio Lobo de Carvalho, Barbosa du Bocage, Laurindo Rabelo, even Mattos-also known as Boca do Inferno (his "cursing lyre")—Charles Baudelaire, Arthur Rimbaud, Allen Ginsberg, and Salvador Novo, whose reckless sonnets Mattoso has translated into Portuguese. Mattoso knows this tradition; he does not intend to innovate with his poetry. Glaucomatoso refers to someone who suffers from glaucoma, but it is also, as previously mentioned, an identity displacement that is at the same time the acknowledgment of a lineage:

Nunca tive veleidades literárias, no sentido de estar fazendo algo original, inovador, ou de vanguarda. Isso não existe. No Brasil, confunde-se vanguarda com elitismo, talvez porque num país semi-analfabeto há pouco espaço pra erudição, e toda \& qualquer 
pesquisa estética, seja na área de criação ou de crítica, parece grande avanço. Em terra de leigo, original é quem plagia primeiro. Para um bom bibliotecário, não existe nada original. A única diferença entre o plagiado e o plagiário é que o nome do primeiro já constava das obras de referência e dos catálogos. (Mattoso, Manual 143)

Mattoso is, therefore, a confessed plagiarist. He entered the literary world during the military dictatorship of the 1970s, publishing Jornal Dobrabil-itself an extremely complex device. Teasing, poking fun at the Jornal do Brasil or the Revista de antropofagia, writing under dozens of heteronyms (García Loca, Petter the Rotten, Pierre le Pourri, Pedro o Podre, and so on), he put on display monstrous and arbitrary re-appropriations, apocryphal citations, and fetishistic propaganda. For the sake of teasing, of being a foot idolizer, a coprophagist, a necrologist, blind and omnivorous, but also bibliophilic and a guerrilla, Mattoso, in his own way, introduces himself into the obscenity of literary tradition.

The two final verses of Sonnet 926 continue to summon the reader, and they perhaps offer the key to Mattoso's work. Were it not for those two verses, one would never know what happens to the foot or why it matters. And it matters because the poetic voice, the one in the first person, is getting something done. "Disgusting, [...] it's a job for Glauco Mattoso," sing The Billy Brothers in the short film Sadomasô, where the poet licks the boots, socks, and feet of a man reading the April 1997 issue of Leg Show, a US adult publication focused on fetishism. What is the blind poet doing on his knees? Was it not, then, just a literary matter? Is that foot adorer, whose tongue loves what other fetishists toss aside, truly Glauco Mattoso? Was not the author already dead? Mattoso thus returns materiality to the anthropophagical metaphor, a pure intellectual abstraction — he does the dirty work. Glaucomatous as he is, Pedro José Ferreira da Silva sees nothing but feet. That is why his (blind) eyes cannot tell the poem's foot from a duck's foot, and such a deformed, stinking, and fetid foot is good for his tongue. It is good for him, the only foot adorer who does not toss it aside.

Just like in Jornal Dobrabil and in Manual do podólatra amador, Mattoso takes charge of what no one else wants, what no one else sees or listens to, the radically alheio, what has already been digested or what no one would ever want to consume: garbage, shit. For Perlongher, this is a process of spatialization and 
specialization. It produces another cartography of the body (a hierarchical reorganization of the intimate parts) and the selection - what I would call an extraordinary maneuver of amplification — of one single part as final destiny of desire. It is the strange logic of sadomasochism-pornological antinomy, according to Gilles Deleuze. That is what the poet is doing there on his knees, his supposedly humiliating spatial and special task, listening with the tongue to the secret music of abject matter, eating garbage - and with pleasure.

Is this a metaphor for the military dictatorship? Is Mattoso's gesture, as Palmeiro has proposed, a "strategy to oppose the body to the torturer as a surface of pleasure"? Is it similar to the 2011 performance by artist Deborah Castillo, a warning about the humiliation brought down on civilians by the oppressive boot of the Venezuelan state? That year, Castillo presented the performance Lamezuela during the annual Velada de Santa Lucía, in Maracaibo, Zulia. ${ }^{4}$ (Is not Saint Lucy of Syracuse the patron of the blind?) At one point during the performance, the artist kneeled and licked the boots of a military officer. It was the symbol of the apathy of a society that even then, before the illness and death of Hugo Chávez, did not seem to understand it was being oppressed.

This was not the case of Mattoso thirty years earlier, however. The Jornal Dobrabil and the Manual do podólatra amador include Mattoso's own advertisements for podolatry and BDSM masters, because the author-that symbolic space formed by the work, the writer, and the reader (Barthes, Image, Music, Text), but also the physical person that speaks or makes all the subjects of the enunciation speak - is a sadomasochist and is searching for masters (and slaves). Seriously. If it is (and it may be) a symbol, it is so ad hoc. If it is (and it may be) a metaphor, it is so by default. He is truly looking for a foot to lick, he truly wants to humiliate and be humiliated, because it excites him sexually. Sonnet 926 is also a peculiar form of sadomasochist performance.

\section{On Blindness}

The sonnet and "O quichute do quíchua" have a relation of mutual engendering and complex proximity. The sonnet opens the short story, but the short story

\footnotetext{
${ }^{4}$ Lamezuela is a combination of the Spanish verb lamer ("to lick") and the two last syllables of Venezuela, which are pronounced exactly the same as the noun suela ("sole of a shoe").
} 
produces the sonnet: "O soneto acima me veio depois que peguei o Nelo de veneta e cobrei dele o caso que me pisa no calo desde criança" (17). Actually, the sonnet is inspired by the story and is, therefore, posterior to it; however, it is also previous in the sense that it already existed as a "fantasy" that the narrator has pursued since his childhood. What is the origin of this "fantasy"? Glauco, who is at the same time a character, the narrator, and the author, wants to know "se mais alguém sente atração por um pé chato igual àquele do moleque que abusara de mim quando eu tinha meus nove anos e a turminha dele uns onze" (17). It is not, then, a fantasy but rather a memory. The narrator follows a memory from childhood, linked to a specific type of foot, the one described in the sonnet. It is the remembrance of an act of abuse or, more precisely, the reinsertion of the abuse into the fantasy. How to understand this gesture in times of the tyranny of the good? How to read many times that the victim of abuse remembers the abuse with erotic tenderness? What does it mean to say that Mattoso's writing serves that which is foul?

The scene is repeated countless times throughout Manual do podólatra amador and in Mattoso's narrative and poetry. In Sonnet 20, one reads:

Um fato me marcou para toda a vida

Aos nove anos fui vítima dos caras

Mais velhos, que brincavam com as taras,

Levando-me da escola para avenida

Curravam-me num beco sem saída,

Zoavam inventando coisas raras,

Como lamber sebinho em suas varas

E encher a minha boca de cuspida

O que dava mais nojo era a poeira

Da sola dos seus tênis, misturada

Com doce, pão, cocô ou xepa de feira.

O gosto do solado e da calçada

$\mathrm{Na}$ língua fez de mim, queira ou não queira,

A escória dos podólatras, mais nada. (26) 
Pedro José Ferreira da Silva became Glauquinho the day a group of teenagers humiliated him physically, psychologically, and sexually. However, Glauquinho is quite far from being a victim. If he keeps the word abuse, he does so because it excites him sexually, not because he writes in defense of any cause. A weak Glauquinho, with glasses that announced his glaucoma and revealed him as an avid reader, defies the official psychogenesis of fetishism. His fetishism comes from a sort of trauma reinserted as joy in literary and real-life compulsion. His foot fetishism is related to abuse and blindness (which, for once, is nonmetaphoric and non-symbolic). As the superhero who suffers the loss of a sense and, as a result, develops superhuman strength in another, Pedro José Ferreira da Silva, SuperGlauco, has prodigious senses of hearing and smell. Like the Freudian fetishist who chooses the last thing he saw as his fetish (mnemic remains, optic remains) before denying the mother's castration, that is, before not seeing what he sees, Mattoso treasures the previous images, not the phallic mother, but the glaucoma:

\section{Em "Laranja mecânica" (A Clockwork Orange), de Stanley Kubrick, o personagem central é o jovem delinqüente que, após passar pela robotizante lavagem cerebral da prisão, é testado diante duma seleta platéia, tendo que obedecer sem reagir a um agressor que o derruba, põe-lhe o pé sobre o rosto e ordena-lhe que lamba, "again and again." O close da língua sob a sola do sapato é uma das imagens mais excitantes que assisti. (Manual 19)}

The narrator's blindness, in the case of the short story, represents a sort of genre marker of pornological literature - the need for a story inside the story. In The 120 Days of Sodom, for instance, Sade gives the storytellers a fundamental role. These are women who must narrate their "adventures" for the pleasure of the libertines. Mattoso, the absolute narrator of Tripé do tripúdio e outros contos hediondos, is in a similar way simply a hunter-gatherer of the anecdotes of other foot idolizers, his friends, his storytellers. He needs detailed descriptions. His own truth is important; however, explicitness is even more so, and these storytellers become his eyes. In "O quichute do quíchua," one might say, it falls to Nelo to undertake Mattoso's search for the very foot that he had been forced to lick as a kid. 
The documentary Filme para poeta cego (2012), written and directed by Gustavo Vinagre and produced with audio for blind people, shows the problem of the author, as well as his blindness, fetishism, and sadomasochism. Let us now return to the aporia. According to Deleuze, there is no such thing as sadomasochism per se. A masochist can also be a sadist, but what he seeks is only expiation, unlike what happens when a sadist is a masochist. In other words, a sadist can be a masochist and vice-versa, and this does not imply confusion between opposing logics or drives. Sadism is institutional, masochism is contractual: sadists, whose madness is possession, are instructors, but masochists, whose madness is the pact, are educators. Such hypotheses are brilliantly confirmed in Filme para poeta cego and Mattoso's work. The writer established certain conditions before participating in the filming of the documentary. For instance, he would not again suffer the abuses of his childhood; someone else had to suffer them instead.

Thus, the film is the (fruitless) search for an actor to play the "role" of Mattoso, in a situation in which Pedro José Ferreira da Silva already occupies that "role." It is the director himself who ends up licking the soles of the poet and being raped, while Mattoso's partner tells the latter what is happening. The director ends up at the feet of the poet, a fact that both humiliates him and perverts his function as director. Mattoso, meanwhile, is sometimes a masochist and sometimes a sadist, but he is always a figure of himself, a character. In " $\mathrm{O}$ quichute do quíchua," the author reappears in masochist mode, a pornological one, which has succeeded in "confronting language with its own limits, with what is in a sense a 'non-language' (violence that does not speak, erotism that remains unspoken)" (Deleuze 27). Frustrated, he recognizes: "Curioso fico em descobrir se outros podólatras tiveram mais chance que eu de cruzar com algo tão raro na anatomia do brasileiro" (“O quichute" 18).

It is now that the story reveals its (anthropological? sociological? cartographic? geopolitical?) nature. The feet for which Mattoso searches turn out to be quite rare in the anatomy of Brazilian men. What does this mean? Given the context ("I am interested only in what is not mine"), it is an unmistakably cannibalistic gesture. But, why the feet? Was this the sacred enemy? Was this the 
taboo that the modernists so persistently wished to turn into a totem? $?^{5}$ According to Palmeiro:

As theory of the cultural hybridization, anthropophagy still respected its sources - mainly the European high culturebecause Tupis believed that eating another human being was an act of homage as well. Meanwhile, coprophagy understands cultural heritage as pure waste. Literally and literarily, shit. Thus, Glauco faces the undesirable waste of anthropophagical digestion, what was not considered relevant or useful for the Brazilian society or its doubtful "progress." Rather than problems of cultural import, Mattoso tackles problems of cultural heritage and their political value, the transmission and distribution of cultural treasuries, which are, as we all know, a privilege of the dominating classes.

Anthropophagy, as a cultural theory, is questionable, but beyond that Mattoso's fetishism toward feet inevitably appears mixed up with his drive to plagiarism (coprophagy, consumption of "feces") as well as with a certain critical nausea at those feet that he idolizes, which stink and taste like shit. The aforementioned scene of "O quichute do quíchua," however, being a scene of consumption, refers to an aspect that Palmeiro avoids, probably because she is commenting on other texts by Mattoso. Judith Butler's Bodies That Matter has been translated into Portuguese as Corpos que importam. In translation, the title loses the pun created with the two meanings of the English word matter, "substance" and "value," but the translation offers, or may offer, another meaning that is essential to this scene in the story. In Portuguese, corpos que importam also means "bodies that import (something)" or "bodies that they import." In this way, the Quechua's foot collects the materiality of the body and its value as a foreign "product." Yes, it is a problem of importation-however, not a cultural importation, like the anthropophagical one identified by Palmeiro, but rather the importation of rotten flesh and its altered sexual and political value.

\footnotetext{
${ }^{5}$ It is important to remember that the entire idea of antropofagia, as formulated by Oswald de Andrade, was inspired by his encounter with Tarsila do Amaral's painting of an enormous foot: the iconic Abaporu (1928).
} 
Before addressing any other detail, Mattoso and Nelo entertain themselvesverbal foreplay-with some (anthropological? sociological? cartographic? geopolitical?) questions about the anatomy of the Brazilian men: "Você tem razão, Glauco, de dizer que brasileiro não costuma ter pé chato. Meu olho é clínico e de longe pego os detalhes. Quase sempre o pé da rapaziada era arqueado e o dedão mais comprimido que os outros dedos, mais "batatudo." Já os pés grandões, do jeito que eu gosto, sempre apareciam, ainda que pé grande também não seja o forte do brasileiro" ("O quichute" 19). The interlocutors in the short story recognize an anatomic impairment on which they comment briefly yet in detail. Nelo shows off his good eye to the blind man and complains that big feet are not frequent in Brazil. Glauco responds with erudition: "Tamanho também é documento, bem lembrado. Gilberto Freyre que o diga. Ele foi quem mais estudou nosso pé pequeno" (19). In the notes to the second chapter of Casagrande \& senzala, Freyre quotes from Tratado descritivo do Brasil em 1587, where Gabriel Soares de Sousa describes Indians with these words: "Bons dentes, alvos, miúdos, sem nunca lhes apodrecerem [...] pernas bem feitas, pés pequenos $[\ldots]$ homens $[\ldots]$ de grandes forças" (138). Glauco is probably referring to this passage, or perhaps another fragment from Freyre's vast corpus. Maybe it is, again, about a sacana. At any rate, national production does not seem to give Glauco and Nelo the "product" that they need - it does not provide enough to one of them, gives almost nothing to the other-and for that reason it has had to be "imported" from Peru.

The rest of the story can be summarized as follows: Nelo tells Glaucopornological story - how he has convinced - logic of persuasion and pact - a young Peruvian crook to allow him to lick his old shoes and feet in exchange for a new pair of shoes or its monetary equivalent. The young man accepts but decides to add a session of oral sex, which does not appear in the story because Glauco interrupts the storyteller saying, "Não, Nelo, nem faço questão" (24). Like in almost the whole of Mattoso's literary production, this story has no happy ending. Uncontrolled genitals, excessive perversion - it is not a text on pleasure but one on jouissance, about the boredom of jouissance as repetition (Barthes, El placer). And jouissance is the waste of pleasure.

How did "O quichute do quíchua" become "El queso del quechua"? Cartonera's edition is bilingual, and all bilingual publication contains waste, which is everything that translation has turned into waste, the original. Why does 
the edition keep such waste? Probably because it treasures it. All bilingual publication is a celebration of waste, coprophilia. In this paper, I have decided to cite, that is, consume, the original text of a bilingual edition in an act of coprophagy. However, how does quichute become cheese? In Portuguese as in Spanish, it is common to link the filth of feet to cheese ("cheiro de queijo nos pés"); the same is true in English ("toe cheese"). It is a transnational metaphor; the translator chose the transnational metaphor, and by doing so, evaded the question of the quichute.

Quichute is the transcription, using the letters of the Portuguese alphabet, of the shoe brand Kichute, owned by São Paulo Alpargatas Company, very popular in Brazil during the 1970s as a result of the euphoria following the country's win of its third soccer championship in the World Cup in Mexico. In a study of lexical variations in some regions of Brazil, Maranúbia Doiron and Vanderci Aguilera offer the following analysis:

À época do lançamento desses calçados, era relativamente comum alguns produtos industrializados serem escritos com letras ditas estrangeiras, ou seja, aquelas que não constavam do alfabeto português. No exemplo do calçado Kichute, a letra "K" fazia as vezes do advérbio "QUE," geralmente utilizado para introduzir orações exclamativas, com o sentido de "QUÃO." Assim, o Kichute aludia a um "que chute!" O emprego da letra "K," bem como o "W" e o "Y" em marcas de fantasia, muitas vezes tinham por função remeter a palavras estrangeiras, sugerindo status e modernidade aos nomes de coisas e de pessoas. (82)

Kichute would then be a sort of sublimated, modern, serially produced, and threetime champion espadrille: the symbol of national pride embodied by a foreign letter and a shoe within reach of the "popular classes." But, soon enough, along came the Kichut (a sort of Asian capitalist translation) to end the party. This Chinese version of the shoe was much cheaper, and without the final "e." It came from far away, was a product for the masses, and turned the Brazilian brand into the "original." The response of São Paulo Alpargatas was to emphasize, precisely, the national character of their shoes. The company added Brazil's yellow-and-green flag to its shoe, but it did not work. São Paulo Alpargatas went 
Castro

bankrupt, and the translation transformed the original into waste. In the story written by Mattoso, the "brand of fantasy" is not only a legal name for a distinctive sign on a registered product. The Peruvian boy's shoe looked like a Quichute - written this way, the Portuguese way - and evoked a waste. It is a brand of fantasy, a fantasy of a gore foot idolizer. Kichute, they said in those days, "costs less, stinks more."

This is the story that Palmeiro's "cheese" eludes and alludes to (by maintaining the Portuguese version of the story). The story of another Indian, a foreign Indian - a crook, a poor man, discarded by Brazil, where he came with the fantasy of becoming a soccer player, frustrated because of his flat foot. This is the secret cartography of "O quichute do quíchua," the routes taken by the desire for the foot and the boot. This is the Mattosian sociology, in which Palmeiro's thesis intervenes. "El queso del quechua" is in fact the material manifestation of Palmeiro's academic hypothesis, or her contribution to the process that she is describing and through which she is thinking. She in fact proposes another story articulated between Brazil and Argentina, a sort of queer smuggling - conveyed by the figure of Perlongher in exile - or a trash antiaesthetics between these two countries that defies institutional order in the cultural context of post-autonomy.

According to Palmeiro, this sexualized and politicized smuggling became a part of the project of cartonera publishers during the Argentine economic crisis of 2001. From the beginning, their catalogues included the (marginal, or desbunde) authors who became known in Argentina through the (literary or sexual) activism of Perlongher and their cooperation with other Brazilian writers and activists. With Eloísa Cartonera, "El queso del quechua" places Palmeiro, forty years later, in Perlongher's position: as a mediator between Brazilian and Argentine garbage.

Thus, as Mattoso's work is the continuous performance of his podolatry, El queso del quechua as an object is a performance of Palmeiro's thesis. It is materially made of garbage; it is made so as to make its own condition of manufacture and its aspect of waste visible. That is what is at stake in the bilingual edition of El queso del quechua for Cartonera: the interweaving of the work and life of Mattoso, a character version of himself; the militant aesthetics circulating between Brazil and Argentina during the twentieth-century dictatorships; but also, the reading that returns from the US academy in a gesture 
of intervention that reproduces the object that it is thinking about and the way it is being thought. Palmeiro proposes that Mattoso's work intends to express that the "cultural treasuries" are not a "privilege of the dominating classes" but garbage. And that is where she produces her performative mediation at the same time as she produces her object of study.

El queso del quechua is a fetish book in the etymological sense of the term, which comes from the Portuguese word feitiço. It was coined by Portuguese navigators to refer to the sacred objects to which Africa's indigenous peoples paid homage — or, perhaps more precisely, their own surprised reaction to these objects. One might justifiably understand the word as operating halfway between the Spanish words hechizo ("spell") and hacer ("to do"). In this sense, Palmeiro "does" her "spell" or "materializes" her thesis. Readers finds themselves handling (and adoring) old cardboard, a material wasted and given new significance, on which a sort of surplus has been printed. This, in the end, is what has been always at the core of fetishism: materialization, the embodiment of otherness, the prototype of all devotion. The problem for readers of El queso del quechua is that what is embodied in Mattoso's book is precisely the stench of the other, his "[foot] cheese." The Cartonera edition of a short story by Mattoso does not attempt to hide its stench; rather, it obtains its strength and foul pulse from that odor.

If Palmeiro has been able to make her object, it is only because Mattoso succeeded. The songs of his language, as Rokha wrote, have eyes and feet- they act. They act because they are alive; they are pés vivos. And here is where theory is forced to create; it is where Freud bowed his enormous head before what Lacan called "vivantes servitudes" 'living servitudes' (486). The desire for the foot does not immobilize desire (the enigma that confronts natural philosophy); it dislocates and disorders it, degenitalizes and partializes it, redistributes it, expands it in ways in which phallogocentric thought and high anthropophagy are unaware. For the former, the fetish is trapped between metaphor and metonymy, within the logic of the symbol; for the latter, incorporating is killing, deactivating. Mattoso's fetish exists on of the margins of reason and consumption as annihilation. Mattoso's work is situated in the separation between the self and the other, without incorporating or annulling it, without thinking it through. It licks and smells it, listening to its music. 


\section{Works Cited}

Barnstone, Willis. Six Masters of Spanish Sonnet. Southern Illinois UP, 1993.

Barthes, Roland. El placer del texto. Translated by Nicolás Rosa, Siglo XXI, 1993.

-. Image, Music, Text. Translated by Stephen Heath, Hill and Wang, 2009.

Butterman, Steven. Perversions on Parade: Brazilian Literature of Transgression and Postmodern Anti-Aesthetics in Glauco Mattoso. San Diego State UP, 2005.

Caixeta, Ana Paula Aparecida. Glauco Mattoso, o antikitsch. 2016, U de Brasília, $\mathrm{PhD}$ Dissertation, repositorio.unb.br/bitstream/10482/22767/1/2016_Ana PaulaAparecidaCaixeta.pdf.

Campos, Pedro Ulysses. "O poeta passado a sujo." Poesia digesta, by Glauco Mattoso. Landy, 2004, pp. 11-17.

Deleuze, Gilles. Presentación de Sacher-Masoch: lo frío y lo cruel. Translated by Irene Agoff, Amorrortu, 2001.

Doiron, Maranúbia Pereira Barbosa, and Vanderci de Andrade Aguilera. "Variantes lexicais para alpargatas no Paraná e na Região Nordeste do Brasil: um estudo etnolinguístico." Signum, vol. 16, no. 2, 2013, pp. 67-99.

Freyre, Gilberto. Casa-grande \& senzala. Global, 2003.

Lacan, Jacques. Escritos 1. Translated by Tomás Segovia, Siglo XXI, 2009.

Mattoso, Glauco. O calvário dos carecas: história do trote estudantil. EMW, 1985.

—. Geléia de rococó: sonetos barrocos. Ciência do Acidente, 1999.

—. Jornal Dobrabil. Iluminuras, 2001.

-. Manual do podólatra amador: aventura \& leituras de um tarado por pés. All Books, 2006.

-. A planta da donzela. Lamparina, 2005.

—. O que é poesia marginal? Brasiliense, 1981.

-. El queso del quechua. Translated by Cecilia Palmeiro, Eloísa Cartonera, 2010.

—. "Sadomasô." YouTube, Carlos Akira Nishimura II, 28 Jul., 2016, youtube.com/watch? $\mathrm{v}=$ orEjjDic2Uc\&t=12s.

—. Tratado de versificação. Annablume, 2010.

Nancy, Jean-Luc. Corpus. Translated by Richard A. Rand, Fordham UP, 2008. 
—. Listening. Translated by Charlotte Mandell, Fordham UP, 2007.

Palmeiro, Cecilia. Desbunde y felicidad: de la Cartonera a Perlongher. Título, 2013.

Perlongher, Néstor. Prosa plebeya: ensayos (1980-1992). Colihue, 1997.

Pietroforte, Antonio Vicente Seraphim. "Posfácio: a construção da realidade segundo Glauco Mattoso." Epilogue. Tripé do tripúdio e outros contos hediondos, by Glauco Mattoso, Tordesilhas, 2011, pp. 175-83.

Rokha, Pablo de. "Ballad of Pablo de Rokha." Translated by Stuart Cooke, Aldus, no. 2, 2011, p. 148.

Sallum, Jorge. "A grande sacanagem histórica de ainda escrever sonetos." Preface. Poesía vaginal, by Glauco Mattoso, Hedra, 2015, pp. 9-26.

Silva, Susana Souto. O caleidoscópio Glauco Mattoso. 2008, U Federal de Alagoas, PhD Dissertation, www.repositorio.ufal.br/bitstream/riufal/522/1/ Tese_SusanaSoutoSilva_2008.pdf.

Vinagre, Gustavo, director. Filme para poeta cego. Performances by Carlos Akira Nishimura and Glauco Mattoso, 2012. 